embraces a vast region reaching, towards the south, to the River Garigliano and having Littoria as its capital.

The new province of Littoria has an area of $2,100 \cdot 3 \mathrm{sq} . \mathrm{km}$. and a population now approaching 200,000 . The capital, Littoria, is a city constituted almost exclusively of offices, business houses, places of assembly, scholastic establishments, hospitals and the like, etc. Its fixed population is only 2,500 , but, like Sabaudia, it has been planned with a view to extensive development in the future.

\title{
To Sir Charles Vernon Boys on his Eightieth Birthday
}

Why does Sir C. V. Boys elect To do the things we least expect, And always choose a task that seems More suited to the land of dreams : A problem other men would shirk, Yet solve the task, and make it work By means that no one else employs ? The answer is: Boys will be Boys!

What made him buy an Otto bikeTwo wheels abreast - a thing to strike Terror in any rider's soul, Yet somehow manage to control Its actions and avoid a spill, And-using his uncanny skillDelight in a precarious poise ? Again we say: Boys will be Boys.

Why snatch a bullet in its flight, Lit by a single spark so bright That on a photographic plate The fleeting shadow seemed to waitWith wake and bow-wave primly setAll posing for their silhouetteAnd leave a picture of the noise? Because, of course, Boys will be Boys !
Why did his bold, untrammelled thoughts Conceive the scheme of fusing quartz, Using an arrow, as it fled, To draw a microscopic thread, And from the fusion to "unreel" A gossamer more true than steel, Which every Physicist enjoys ? The fact is this: Boys will be Boys.

What made our friend so seeming rash As to pursue a lightning flash By lenses rapidly revolved, And even get the problem solvedBoth of its speed and structure-by A photograph "which cannot lie"? That gave a thrill that never cloys, And showed us still, Boys will be Boys.

To weigh the earth-to check the ThermExplain the logarithmic term-

To build with bubbles, and maintain

The opal colours in their train !

These are his pleasures, these his ploys

(Where skill with mind and Truth alloys)

For which, in Science, as in Toys, We thank our stars, Boys will be Boys!

R. A. S. P.

\section{Obituary}

\section{SIr GeORge Cory}

$\mathrm{S}^{\mathrm{s}}$ IR GEORGE CORY, who died on May 7 at seventytwo years of age, had spent forty-four years of his life in South Africa. He received his scientific training at King's College, Cambridge, where he took honours in the Natural Sciences Tripos in 1888. After holding various academic appointments in the schools of Grahamstown, which is in the Eastern Province of Cape Colony, he was appointed professor of chemistry in Rhodes University College in 1904, and occupied the chair with great distinction until his retirement with the title of professor emeritus in $\mathbf{1 9 2 5}$.

Cory was undoubtedly a good teacher and was beloved both by his colleagues and his students, whom he could, and did, inspire with his own enthusiasm. Indeed, some of his men have done extraordinarily well, but the truth is that though his heart was in his work, his real interest in life lay elsewhere. As a consequence of this, no scientific discoveries of any great value can be placed to his eredit. He had neither the temperament nor the vision for chemical or physical research, and as
Rhodes College was off the beaten track, there were no chemical souls with whom he could commune.

Cory was really an antiquary. Very soon after his arrival at Grahamstown, where much of the early South African history was enacted, he realised, as indeed did others, that records of the doings of the 1820 settlers and of others would soon be lost if an attempt was not made to collect them. While others talked, Cory acted. He never took a holiday, but spent all his spare time in trudging over the country, covering great distances, enduring much physical discomfort, to carry on his self-imposed task. All interested in South Africa know that his "Rise of South Africa", in six volumes, was practically completed some little time ago. For his work in this and in other but similar directions, Cambridge awarded him the honorary degree of D.Litt. in 1921, and when he was knighted in 1922 he came to England, which he had not seen for more than thirty years, and did further historical research. He was awarded the gold medal of the Royal Empire Society in 1933. 